\title{
Temporal Changes in Crop Diversification and Advantageous Crop in Amravati District of Maharashtra State, India
}

\author{
K.V. Lakshmi ${ }^{1^{*}}$ and S.C. Nagpure ${ }^{2}$ \\ ${ }^{1}$ M. Sc. Agricultural Economics, Post Graduate Institute, Dr. Panjabrao Deshmukh Krishi \\ Vidyapeeth, Akola, Maharashtra, India \\ ${ }^{2}$ Department of Agricultural Economics, College of Agriculture, Nagpur, Maharashtra, India \\ *Corresponding author
}

\section{A B S T R A C T}

\begin{tabular}{|c|}
\hline Keywords \\
\hline $\begin{array}{l}\text { Cropping pattern, } \\
\text { Crop } \\
\text { diversification, } \\
\text { Advantageous crops }\end{array}$ \\
\hline Article Info \\
\hline $\begin{array}{l}\text { Accepted: } \\
\text { 15 September } 2018 \\
\text { Available Online: } \\
10 \text { October } 2018\end{array}$ \\
\hline
\end{tabular}

\section{Introduction}

Crop diversification has emerged as an important alternative to attain the objectives of output growth, employment generation and natural resources, sustainability in the developing countries.

To meet the challenges of a globalizing market in agriculture as well as the growing and changing needs of the population many countries in South East Asia have undertaken
The present study was based on secondary data collected from a period of 43 years i.e. from $1970-71$ to $2013-14$ by examined changes in cropping pattern, the trend in crop diversification, and advantageous crops in Amravati district of Maharashtra. Simple tabular analysis was used to examine the changes in cropping pattern in Amravati district. In order to study the crop diversification Herfindahl index had used for analytical tools. In order to work out the advantageous crops, land concentration ratio in Amravati district of Maharashtra with comparative advantage was computed for last 10 years i.e. from 2004-05 to 2013-14. There existed wide temporal changes in the cropping pattern of Amravati district. Over a period of study, the proportions of area under jowar and cotton had reduced in Amravati, whereas it was increased in respect of gram. Soybean attained prestigious position in the cropping pattern of Amravati. In Amravati district crop diversification has significantly increased during the study period. The diversification from subsistence crop to more commercial crops were took place in Amravati. Cotton and Soybean shows increasing land concentration ratio from year 2009-10 to 2013-14, in both of these crops soybean is more advantageous crop in Amravati district. 
Cropping pattern has been dynamic to cope up the changing scenario and to meet ever changing demands of growing population. Limited availability of land raising population and declining yields, forced farmers to search for alternate ways for raising farm income, with the passage of time farmers because increasingly commercialized and started farming for maximizing their output. Now the realization prevails amongst the farmers for the long term returns, and they are in search of optimum cropping pattern which can fulfill their aspirations. It is also found that the higher the technical inputs, lesser the degree of diversification. The cropping pattern usually changes over time with the development of agriculture, as is evident in the case of agriculture in India (Vyas, 1996).

The main advantage of the study of crop diversification regions lies in the fact that it enables to understand that impact of physical and socio economics conditions on the agricultural mosaic. Moreover, it help to know the contemporary competition among the crops for an area and scope for rotation and effect on double cropping, total production and per hectare productivity. Hence, the present study was undertaken in Amravati district with following objectives.

The main objectives of this study, to study the temporal changes in cropping pattern in Amravati district. And to study the crop diversification in Amravati district. Also, to work out the advantageous crops in Amravati district.

\section{Materials and Methods}

The present study pertains to Amravati district in Amravati division of Maharashtra State. The present study was based on secondary data collected from various government publications and pertains to a period of 43 years i.e. from 1970-71 to 2013-14. For the study all the major food grain and non-food grain crops of Amravati district which occupied more than 80 percent of the gross cropped area were selected. Thus, present study was confined to major crops with an assumption that excluded crops do not affect cropping pattern and in turn would not vitiate main conclusions of the study. The eleven crops are selected for present study like Rice, Wheat, Soybean, Cotton, Jowar, Bajra, Gram, Tur, Mung, Groundnut and Sugarcane.

\section{Analytical tools}

\section{Cropping pattern}

Simple tabular analysis for 43 years was used to study the cropping pattern of Amravati district.

\section{Crop diversification}

\section{Herfindahl index (HI)}

In order to study the crop diversification Herfindahl index have been used.

$\mathrm{HI}=$

Where,

$\mathrm{N}=$ The total number of crops.

$\mathrm{Pi}=$ Proportion of acreage under $\mathrm{i}^{\text {th }}$ crop to total cropped area.

\section{Advantageous crop}

In order to work out the advantageous crops, land concentration ratio in Amravati district of Maharashtra state with comparative advantage was computed for last 10 years i.e. from 2004-05 to 2013-14. The comparative advantage was here approximated by the per hector net revenue of each crop relative to the average revenue of the remaining crops. 


\section{Results and Discussion}

\section{Changes in cropping pattern in Amravati} district

The changes in cropping pattern in Amravati district of Maharashtra during 1970-71 to 2013-14 are presented in Table 1.

In the span of 44 years cropping pattern has changed substantially. The proportion of area under jowar by 3.32 per cent, cotton by 17.61per cent and groundnut per cent has been reduced while tur by 9.08 per cent, gram by 8.48 per cent, mung by 4.79 per cent and soybean by 34.57 per cent have been increased by the end of the year 2013-14.

In case of cotton, its share over gross cropped area has reduced to 17.61 per cent in 2013-14 from 51.33 percent in 1970-71 which is still emerged as the major crop in the division. The constant proportion of area under other pulses over gross cropped was highest in 2000-01 i.e. 3.26 percent. Soybean crop is being cultivated to the extent of 34.57 per cent of gross cropped area. The percentage change over base period 1990-91 of soybean is 1081.94 per cent which indicates increase of acreage under this crop. The area of rice, jowar, bajra, other cereals, mung, other pulses, sugarcane, cotton, groundnut and other oilseeds have been shifted to soybean.

There is positive change in gram by 204.75 per cent, other crops by 1364.29 per cent, tur by 15.76 per cent next to soybean over base period 1990-91. The gross cropped area has increased by 21.17 per cent over base period 1990-91.

\section{Measurement of crop diversification by Herfindahl Index}

Herfindahl Index is also a measure of concentration. The value of Herfindahl Index varies from zero to one. It takes the value one when there is complete specialization and value zero when there is perfect diversification. Accordingly it is presented in Table 2.

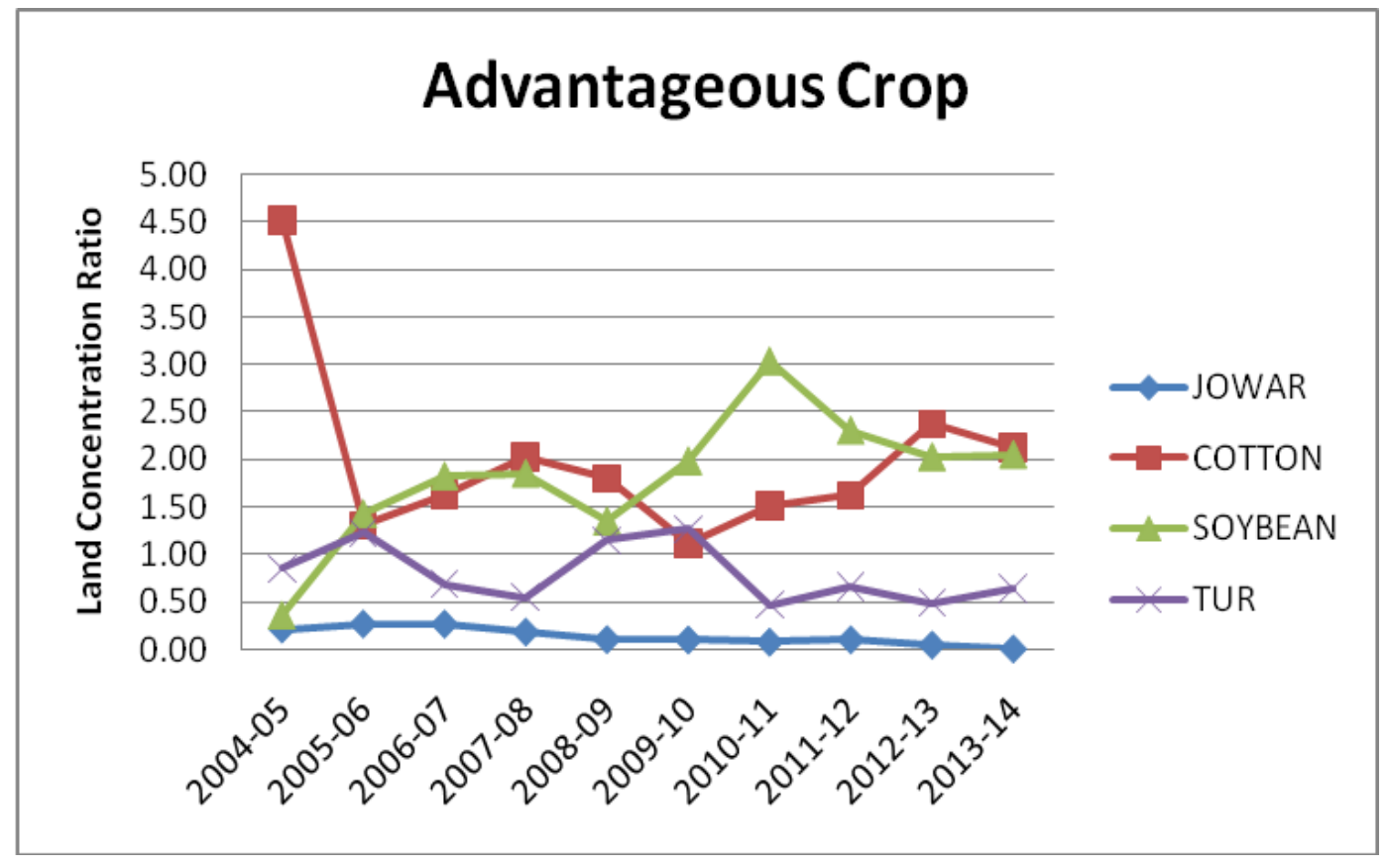


Table.1 Changes in cropping pattern in Amravati District

\begin{tabular}{|c|c|c|c|c|c|c|c|}
\hline & & & & & & (Ar & a na) \\
\hline Sr. No & Crops & & & Years & & & Percentage \\
\hline & & 1970-71 & $1980-81$ & 1990-91 & 2000-01 & 2013-14 & $\begin{array}{l}\text { change over } \\
\text { base period }\end{array}$ \\
\hline 1 & Rice & $\begin{array}{c}91 \\
(1.29)\end{array}$ & $\begin{array}{c}115 \\
(1.49)\end{array}$ & $\begin{array}{c}143 \\
(1.63)\end{array}$ & $\begin{array}{c}89 \\
(0.87)\end{array}$ & $\begin{array}{c}47 \\
(0.44)\end{array}$ & -67.13 \\
\hline 2 & Wheat & $\begin{array}{c}320 \\
(4.54)\end{array}$ & $\begin{array}{c}462 \\
(5.98)\end{array}$ & $\begin{array}{c}308 \\
(3.52)\end{array}$ & $\begin{array}{c}134 \\
(1.30)\end{array}$ & $\begin{array}{c}180 \\
(1.70)\end{array}$ & -41.56 \\
\hline 3 & Jowar & $\begin{array}{c}1601 \\
(22.74)\end{array}$ & $\begin{array}{c}1824 \\
(23.61)\end{array}$ & $\begin{array}{c}1792 \\
(20.48)\end{array}$ & $\begin{array}{c}1188 \\
(11.55)\end{array}$ & $\begin{array}{c}352 \\
(3.32)\end{array}$ & -80.36 \\
\hline 4 & Bajra & $\begin{array}{c}57 \\
(0.81)\end{array}$ & $\begin{array}{c}76 \\
(0.98)\end{array}$ & $\begin{array}{c}37 \\
(0.42)\end{array}$ & $\begin{array}{c}9 \\
(0.09)\end{array}$ & $\begin{array}{c}0 \\
(0.00)\end{array}$ & -100.00 \\
\hline 5 & Other cereals & $\begin{array}{c}57 \\
(0.81)\end{array}$ & $\begin{array}{c}98 \\
(1.27)\end{array}$ & $\begin{array}{c}53 \\
(0.61)\end{array}$ & $\begin{array}{c}53 \\
(0.52)\end{array}$ & $\begin{array}{c}14 \\
(0.13)\end{array}$ & -73.58 \\
\hline 6 & Gram & $\begin{array}{c}69 \\
(0.98)\end{array}$ & $\begin{array}{c}113 \\
(1.46)\end{array}$ & $\begin{array}{c}295 \\
(3.37)\end{array}$ & $\begin{array}{c}366 \\
(3.56)\end{array}$ & $\begin{array}{c}899 \\
(8.48)\end{array}$ & 204.75 \\
\hline 7 & Tur & $\begin{array}{c}371 \\
(5.27)\end{array}$ & $\begin{array}{c}358 \\
(4.63)\end{array}$ & $\begin{array}{c}831 \\
(9.50)\end{array}$ & $\begin{array}{c}996 \\
(9.68)\end{array}$ & $\begin{array}{c}962 \\
(9.08)\end{array}$ & 15.76 \\
\hline 8 & Mung & $\begin{array}{c}95 \\
(1.35)\end{array}$ & $\begin{array}{c}152 \\
(1.97)\end{array}$ & $\begin{array}{c}682 \\
(7.80)\end{array}$ & $\begin{array}{c}616 \\
(5.99)\end{array}$ & $\begin{array}{c}508 \\
(4.79)\end{array}$ & -25.51 \\
\hline 9 & Other pulses & $\begin{array}{c}83 \\
(1.18)\end{array}$ & $\begin{array}{c}94 \\
(1.22)\end{array}$ & $\begin{array}{c}97 \\
(1.11)\end{array}$ & $\begin{array}{c}335 \\
(3.26)\end{array}$ & $\begin{array}{c}14 \\
(0.13)\end{array}$ & -85.57 \\
\hline 10 & Sugarcane & $\begin{array}{c}2 \\
(0.03)\end{array}$ & $\begin{array}{c}2 \\
(0.03)\end{array}$ & $\begin{array}{c}17 \\
(0.19)\end{array}$ & $\begin{array}{c}35 \\
(0.34)\end{array}$ & $\begin{array}{c}3 \\
(0.03)\end{array}$ & -82.35 \\
\hline 11 & Cotton & $\begin{array}{c}3614 \\
(51.33)\end{array}$ & $\begin{array}{c}3507 \\
(45.40)\end{array}$ & $\begin{array}{c}3730 \\
(42.64)\end{array}$ & $\begin{array}{c}3091 \\
(30.04)\end{array}$ & $\begin{array}{c}1867 \\
(17.61)\end{array}$ & -49.95 \\
\hline 12 & Soybean & - & - & $\begin{array}{c}310 \\
(3.54)\end{array}$ & $\begin{array}{c}1803 \\
(17.52)\end{array}$ & $\begin{array}{c}3664 \\
(34.57)\end{array}$ & 1081.94 \\
\hline 13 & Ground nut & $\begin{array}{c}409 \\
(5.81)\end{array}$ & $\begin{array}{c}316 \\
(4.09)\end{array}$ & $\begin{array}{c}292 \\
(3.34)\end{array}$ & $\begin{array}{c}66 \\
(0.64)\end{array}$ & $\begin{array}{c}38 \\
(0.36)\end{array}$ & -86.99 \\
\hline 14 & Other oilseeds & $\begin{array}{c}1 \\
(0.01)\end{array}$ & $\begin{array}{c}2 \\
(0.03)\end{array}$ & $\begin{array}{c}21 \\
(0.24)\end{array}$ & $\begin{array}{c}72 \\
(0.70)\end{array}$ & $\begin{array}{c}2 \\
(0.02)\end{array}$ & -90.48 \\
\hline 15 & Other Crops & $\begin{array}{c}271 \\
(3.85)\end{array}$ & $\begin{array}{c}606 \\
(7.84)\end{array}$ & $\begin{array}{c}140 \\
(1.60)\end{array}$ & $\begin{array}{c}1436 \\
(13.96)\end{array}$ & $\begin{array}{c}2050 \\
(19.34)\end{array}$ & 1364.29 \\
\hline & $\begin{array}{l}\text { Gross cropped } \\
\text { area }\end{array}$ & $\begin{array}{c}7041 \\
(100.00)\end{array}$ & $\begin{array}{c}7725 \\
(100.00)\end{array}$ & $\begin{array}{c}8748 \\
(100.00)\end{array}$ & $\begin{array}{c}10289 \\
(100.00)\end{array}$ & $\begin{array}{c}10600 \\
(100.00)\end{array}$ & 21.17 \\
\hline
\end{tabular}

Figures in the parenthesis are percentages over gross cropped area.

Note: Base period 1990-91 had taken for all the crops according to soybean cropping.

Table.2 Measurement of crop diversification by Herfindahl index

\begin{tabular}{|c|c|}
\hline Year & Amravati \\
\hline $\mathbf{1 9 7 0 - 7 1}$ & 0.30 \\
\hline $\mathbf{1 9 8 0 - 8 1}$ & 0.26 \\
\hline $\mathbf{1 9 9 0 - 9 1}$ & 0.19 \\
\hline $\mathbf{2 0 0 0 - 0 1}$ & 0.17 \\
\hline $\mathbf{2 0 1 3 - 1 4}$ & 0.19 \\
\hline
\end{tabular}

Note :- $>0.5$ - indicate - diversification

$<0.5$ - indicate - non significant 
Table.3 Land concentration ratios of major crops in Amravati district

\begin{tabular}{|c|c|c|c|c|}
\hline YEAR & JOWAR & COTTON & SOYBEAN & TUR \\
\hline $\mathbf{2 0 0 4 - 0 5}$ & 0.22 & 4.52 & 0.37 & 0.86 \\
\hline $\mathbf{2 0 0 5 - 0 6}$ & 0.27 & 1.31 & 1.43 & 1.23 \\
\hline $\mathbf{2 0 0 6 - 0 7}$ & 0.27 & 1.64 & 1.83 & 0.69 \\
\hline $\mathbf{2 0 0 7 - 0 8}$ & 0.18 & 2.03 & 1.86 & 0.56 \\
\hline $\mathbf{2 0 0 8 - 0 9}$ & 0.11 & 1.81 & 1.36 & 1.16 \\
\hline $\mathbf{2 0 0 9 - 1 0}$ & 0.10 & 1.12 & 1.99 & 1.27 \\
\hline $\mathbf{2 0 1 0 - 1 1}$ & 0.08 & 1.52 & 3.03 & 0.47 \\
\hline $\mathbf{2 0 1 1 - 1 2}$ & 0.10 & 1.63 & 2.31 & 0.66 \\
\hline $\mathbf{2 0 1 2 - 1 3}$ & 0.05 & 2.38 & 2.03 & 0.48 \\
\hline $\mathbf{2 0 1 3 - 1 4}$ & 0.01 & 2.12 & 2.05 & 0.64 \\
\hline
\end{tabular}

The Table 2 revealed that in Amravati, the value of Herfindahl Index were found low i.e. less than 0.5 it means in all selected district diversification took place. The diversification from subsistence crop to more commercial crops were took place in these districts. Therefore, from the foregoing analysis that, the hypothesis has been proved respectively crop diversification are took place over a period of time.

\section{Advantageous crops in Amravati district}

Land concentration ratios of major crops in Amravati district were presented in Table 3. From the table, it is seen that, the land concentration ratio of cotton showed increasing trend over a period of study. It means cotton is most advantageous crop in Amravati district over other selected crops i.e. jowar, soybean and tur in Amravati district. Similarly, in the last decade soybean also showed increasing trend in land concentration ratios. Therefore soybean is also an advantageous crop during the last decade.

Areal growth rate of soybean was positively significant in Amravati district at 1\% level of significance. Cotton is more advantageous crop over jowar, soybean and tur crops in Amravati. Soybean also showed increasing trend in land concentration ratios in the last decade so it is also more advantageous crop. Soybean crop is being cultivated to the extent of 34.57 per cent of gross cropped area. The area of rice, jowar, bajra, other cereals, mung, other pulses, sugarcane, cotton, groundnut and other oilseeds have been shifted to soybean. The percentage change over base period 1990-91 of soybean is 1081.94 per cent which indicates increase of acreage under this crop. Hence over a period of study cropping pattern has changed and crop diversification has increased significantly in Amravati district.

\section{References}

Ahmad Fahim Rahimi. 2012. An economic analysis of changes in cropping pattern in Karnataka. Karnataka J. Agric. Sci., 25(4).

Ananya Chakraborthy. 2012. Crop Diversification in Murshidabad District, West Bengal: A Spatio-temporal Analysis. International Journal of Physics and Social Sciences. 2(7): 393403.

Takashi Kurosaki. 2003. Specialization and diversification in agricultural Transportation. The case of West 
Punjab. American J. Agril. Econ. 82 (2):372-386.

Tingre, A.S., S.J. Kakde and A.B. Thakare.2007. Growth rates and cropping pattern changes in Amravati division of Vidarbha. PKV. RES.J.31 (2): $175-179$.

Vyas, V. S. 1996. Diversification in Agriculture: Concept, Rationale and Approaches, Indian Journal of Agril. Economics 51(4): 636-643.

\section{How to cite this article:}

Lakshmi, K.V. and Nagpure, S.C. 2018. Temporal Changes in Crop Diversification and Advantageous Crop in Amravati District of Maharashtra State, India. Int.J.Curr.Microbiol.App.Sci. 7(10): 1769-1774. doi: https://doi.org/10.20546/ijcmas.2018.710.201 